УДК $327.8(510+669)$ «20/21»

DOI: $10.26693 /$ ahpsxxi2020.02.042

\title{
ПРОБЛЕМИ ТОРГОВЕЛЬНО-ЕКОНОМІЧНИХ ВІДНОСИН КНР І НІГЕРЇ̈ НА ПОЧАТКУ ХХІ СТОЛІТТЯ
}

\author{
Ірина Габро, \\ e-mail:irngabro@gmail.com \\ ORCID: https://orcid.org/oooo-ooo1-8215-7615 \\ Чорноморсъкий національний університет імені Петра Могили, \\ Україна, 54оо3, м. Миколаїв, вул. 68 Десантників, 10 \\ Apmyp Акопов, \\ e-mail: dalless20o8@gmail.com \\ ORCID: https://orcid.org/oooo-ooo2-2252-8565 \\ Чорноморсъкий національний університет імені Петра Могили, \\ Україна, 54оо3, м. Миколаїв, вул. 68 Десантників, 10
}

Нігерія та Китайсъка Народна Республіка розвинули тісні відносини, які включають: китайсъкі інфраструктурні проекти, інвестицї, позики, торгові угоди, передачу технологій, культурний обмін тощо. Нігерія є однією з краӥн, що швидко розвиваються у тропічній Африці. Найважливішим джерелом державного бюджету Нігерї $е$ експорт переважно сирої нафти й інших природних ресурсів. Тож Китай має інтерес у відносинах з Нігерією, даючи багато позик, інвестуючи у нігерійсъку інфраструктуру, створюючи китайсъкі культурні центри по всій Нігерї.

У статті описано торговельно-економічні відносини між Китаєм і Нігерією у першому десятилітті XXI століття. Досліджено основні питання торговоекономічних відносин Китаю та Нігерї, вивчено конкретні сфери економічних проблем. Особливості китайсько-нігерійських торговельно-економічних відносин мало розкриваються у дослідженнях вітчизняних вчених, щзо має відношення до цъого дослідження.

Ключові слова: Нігерія, КНР, торгівельні відносини, економічні відносини, інвестицї, кредит, експорт, імпорт, текстиль, безробіття

Постановка проблеми. Торгівельні й економічні відносини КНР і Нігерії $€$ прикладом відносин двох асиметричних акторів міжнародних відносин, де сильніший актор (Китай) просуває свої інтереси успішніше та ефективніше, ніж слабший (Нігерія). Нігерія відверто поступається у конкурентній спроможності китайським компаніям, які працюють на її території або експортують свої товари до неї. Дане дослідження є актуальним на тлі всесвітньої залежності від китайської продукції, яка витісняє місцевого виробника через свою дешеву ціну, такі наслідки вже потягли за собою загострення торгівельних відносин КНР із США, що переросли у тарифну та торговельну війни.

Аналіз попередніх досліджень. Особливості торговельно-економічних відносин між КНР і Нігерією на початку XXI ст. досліджуються закордонними науковцями. Зокрема, праці нігерійських, англійських і китайських науковців. Вчені Акінрінаде Сола й Олукоя Оген, Маргарет Егбула та Чі Чжен, М. Ріндап ${ }^{1}$ детально

\footnotetext{
${ }^{1}$ Akinrinade, S., Olukoya, O. (2008). Globalization and deindustrialization: South-South neoliberalism and the collapse of the Nigerian textile industry. The Global South, 2 (2), 159-170; Egbula, M., Qi, Z. (2011). China and Nigeria: A powerful south-south alliance. West African Chal-
} 
аналізують історію товарообігу між КНР і Нігерією та визначають торгівельний дисбаланс, досліджують дипломатичні відносини між КНР і Нігерією, економічну співпрацю у рамках системи Південь-Південь, розкривають проблему безробіття в Нігерії та вплив на це китайських компаній, які ведуть свою діяльність на теритоpiї Нігерії. Ян Тейлор, вчений з Великої Британії, дослідив відносини Нігерії та Китаю в економічній сфері, аналізуючи китайські інвестиції, інфраструктурні проекти та проблеми корупції нігерійських чиновників².

Метою дослідження є проаналізувати торговельні та економічні відносини між КНР і Нігерією на початку XXI ст., зокрема, з'ясувати особливості китайськонігерійських торговельно-економічних відносин зазначеного періоду та розкрити проблеми, що склалися.

Методи та прийоми дослідження. Методологічним підгрунтям дослідження стали принципи наукового пізнання - історизму, об'єктивності, системності, багатофакторності та детермінізму. Завдяки принципу історизму було проаналізовано зміст та основні питання співробітництва Китаю з Нігерією. У ході дослідження було застосовано сукупність загальнотеоретичних і спеціальних методів. До загальнотеоретичних методів, які застосовані авторами, належать методи аналізу і синтезу, індукції та дедукції, узагальнення й абстрагування, а також групування. Для розв'язання визначених наукових завдань і вивчення поставленої проблеми були застосовані системний, синхронний, компаративний методи.

Виклад основного матеріалу. Торгові відносини між Нігерією та Китаєм якісно відрізняються від аналогічних відносин з іншими країнами. Китай домінує на нігерійському ринку та виступає як найбільший торговий партнер Нігерії. Зовнішня політика та стратегія Китаю відкриває цій країні легкий доступ до товарів і ринків, витісняючи інших конкурентів, що робить Китай більш привабливим як торговельного партнера.

Торгові відносини між Нігерією та Китаєм розпочалися у 1972 р. технічним співробітництвом, яке включало в собі і торгівлю3. У цей період співпраця двох країн була унікальною, оскільки вона мала відкритий характер і дозволяла реалізовувати необмежену кількість проектів. Між 1972 і 1974 роками експорт Китаю до Нігерії склав мільйони доларів. У 1975 і 1976 роках нігерійський імпорт з Китаю склав 69,86 млн. дол. і 140,87 млн. дол. До 1995 р. двосторонній товарообіг подвоївся до 210 млн. доларів і до 830 млн. доларів у 2000 р відповідно4.

Дисбаланс китайсько-нігерійської торгівлі був величезний, і це стало проблемою уряду Нігерії. Хоча нігерійський експорт до Китаю зріс з 60 млн. дол. США в 1995 р. до 293 млн. дол. США у 2000 р., перевага все ж була в КНР з експортом $73 \%$ у двосторонній торгівлі та $68 \%$ у 2000 р. відповідно. Несприятливий торговий дисбаланс з часом лише погіршувався, оскільки до 2008 р. він складав 7,3 млрд. доларів, при цьому китайський експорт становив 93\% двосторонньої торгівлі.

Близько 87\% нігерійського експорту до Китаю - це нафтопродукти, тоді як Китай експортує різноманітні товари до Нігерії, такі як машини та транспортне обладнання, текстиль, одяг, взуття, сільськогосподарська сировина, електроніка та деталі.

Торговий дисбаланс призвів до значної кількості проблем у Нігерії. Нігерійські профспілки звинувачують китайський імпорт у втраті робочих місць для 350000

lenges; Rindap, M.R. (2015). An Assessment of Nigeria-China Economic Relations from 19992014. International Journal of Arts and Humanities, 4 (1), 18-30.

${ }^{2}$ Taylor, I. (2007). China's relations with Nigeria. Round Table, 96 (392), 10, 631-645.

3 Ogunsanwo, A. (2008). A tale of two giants: Nigeria and China. In Kweku Ampiah, Sanusha Naidu (eds.) Crouching tiger, hidden dragon Africa and China (pp.101). Scottsville, South Africa.

${ }^{4}$ Mthembu-Salter, G. (2009). Elephants, ants and superpowers: Nigeria's relations with China. South African Institute of International Affairs, 11. 
нігерійців, головним чином у текстильному секторі. Слід відзначити, що від великих обсягів китайського імпорту зменшилась кількість робочих місць у Нігерії, Ефіопї̈ та ПАР.

Частка торгівлі між КНР і Нігерією становила понад 17\% від загальної торгівлі між Китаєм і державами тропічної Африки, що робить Нігерію другим за величиною торгівельним партнером КНР у цьому регіоні5.

Загалом, Нігерія експортує до Китаю продукти харчування, сиру сировину, олії, хімічні продукти та промислові товари. Але, мінеральне паливо та мастила становлять найвищий відсоток експорту до Китаю через їх значущість. Оскільки основним імпортом до Китаю є мінеральні та пов'язані з ними продукти, більшу частину прибутків отримує уряд і нафтові компаніїб. Тому експорт Нігерії до Китаю безпосередньо не приносить прямої користі громадянам Нігерії та може бути отриманий через державні витрати на сферу послуг країни7.

Китайський імпорт текстилю до Нігерії домінує у секторі торгівлі та має вплив на місцеві ринки разом з іншими імпортованими товарами. Цього було досягнуто завдяки його дешевій ціні порівняно з товарами місцевого виробництва або західними товарами. Більшість нігерійських споживачів майже не думають про якість товарів, які вони купують, оскільки ціна $є$ більш привабливою. Деякі споживачі впевнені, що товари місцевого виробництва $\epsilon$ неякісними, не так добре упаковані та не застосовують сучасні технології8. На додаток до зареєстрованої торгівлі, яка впливає на торговий дисбаланс, існує велика кількість незафіксованої торгівлі між Китаєм і Нігерією9.

Більша частина торгівлі здійснюється через сусідні держави з відсутністю контролю. Бенін, який має найближчий до Нігерії кордон, знаний як район, де значна кількість товарів переправляється до Нігерії. Щільність цього руху створила зручну систему перевезення товарів по обидва боки кордону, що полегшується корумпованими чиновниками з обох сторін, які дозволяють завезення товарів після отримання хабарів. Через такі проблеми, важко отримати реальні цифри торгівлі між обома країнами. Чорний ринок також створює велику кількість проблем у торгових відносинах через постійну контрабанду. Контрабанда товарів через кордони та підкуп митниці збільшилася і впливає на місцеві ринки.

У лютому 2006 р. митний департамент Нігерії засудив грубе порушення нормативних актів Нігерії щодо імпорту й експорту товарів китайськими торговцями у різних містах. Митні органи також зафіксували вантажі контрабандних товарів, що ввозяться в країну за загадкових обставин китайським бізнесом за допомогою зацікавлених громадян Нігерії. Це вплинуло на місцеві ринки, які програвали у конкуренції з контрабандними дешевими товарами, врешті-решт це призвело до арешту кількох китайських контрабандистів. У результаті високої щільності імпорту та нелегальних товарів, ринок Нігерії зараз має цілі китайські квартали, де товари продаються без проходження через пункти пропуску митної служби Нігерії.

Китайське містечко у Лагосі - торговий район, також відомий як торгова зона, де діють китайські підприємства. Китайці залучені до керування Nigeria Limited ${ }^{10}$. Введення пільгових квот на текстиль для держав Африки у рамках Африканського

\footnotetext{
5 Ndubisi, O., Kew, D. \& Tanko, Y. (2008). «Peaceful rise» and human rights: China's expanding relations with Nigeria. In Robert I. Rotberg (ed.). China into Africa: Trade, aid and influence, 176.

6 Olawale, O., Bankole, A. \& Adewuyi, A. (2008). China-Nigeria economic relations. AERC Scoping Studies on China-Africa Relations, 7.

7 Ibidem.

${ }^{8}$ Ibid, 9.

9 Mthembu-Salter, G. (2009).

${ }^{10}$ Oyeranti, O., Babatunde, A.M., Ogunkola, O.E. \& Bankole, A.S. (2010). China-Africa investment relations: A case study of Nigeria. African Economic Research Consortium (AERC), 61.
} 
закону про можливості зростання (AGOA) заохочували китайські фірми формувати торговельні операції у Нігерї та використовувати можливості, які пропонує AGOA $^{11}$. Пільги AGOA та текстильна квота для країн Африки були основними причинами створення чайнатаунів. Місцеві зразки текстилю шахрайським чином копіюються та передаються для масового виробництва китайцям. Таким чином, тканини з Китаю надходять із вкраденими нігерійськими етикетками, розповсюджуються у Нігерії, експортуються до США. Ринок складається зі 120 магазинів, 75\% яких належать китайцям. Китайські фірми у Нігерії виробляють частину готової продукції, тоді як більшість 3 них імпортуються з Китаю ${ }^{12}$.

Нелегальні товари, китайські квартали, чорні ринки та дисбаланс торгівлі все це результат китайського імпорту до Нігерії, і це вплинуло на місцеві ринки, а також інші сектори економіки.

Оскільки більшість імпорту з Китаю є готовою продукцією, вони конкурують 3 нігерійськими вітчизняними виробниками, а імпорт становить відтік для нігерійської економіки ${ }^{13}$. Це призвело до суперечливих торгових відносин між обома державами, оскільки імпорт негативно впливає на національний дохід Нігерії. Імпорт Нігерії з Китаю також грає подвійну роль, оскільки цей імпорт також призвів до зростання залежності через велике споживання китайських товарів. Високе споживання збільшує попит, що, у свою чергу, збільшує імпорт з КНР. Але якщо імпорт переважає експорт у країні, то економічний розвиток загальмовується.

Безробіття відіграє важливу роль у зростанні занепокоєння нігерійців. Нігерія виявилася ідеальним місцем для китайських компаній через велику кількість споживання місцевим населенням їхніх товарів, що потребує дешевої продукції.

Присутність китайських компаній у Нігерії виявляється не такою чудовою для нігерійців. Незважаючи на це, промислові та виробничі компанії Нігерії були непродуктивні. Торгова політика Китаю була несприятливою для нігерійської промисловості. Ї̈̈ політика зумовлена деіндустріалізацією у Нігерії14.

Масовий імпорт китайського текстилю спустошив нігерійську текстильну промисловість, масово скоротивши місцеве виробництво. До заходу на нігерійський ринок китайських тканин, нігерійський текстиль 3 точки зору інвестицій, складав основу галузі промисловості з найбільшим приватним сектором ${ }^{15}$. Промисловість впоралася з місцевим попитом та експортувала свою надлишкову продукцію. Китайський текстиль забезпечує нігерійцям дешевий доступ до різноманітних тканин, що є привабливим і вигідним для нігерійців, але у довгостроковій перспективі може мати фатальні наслідки для нігерійського текстильного сектору та економіки у цілому, оскільки це руйнує місцевий виробничий потенціал і конкурентоспроможність, що також стримує іноземні інвестиції у нігерійську текстильну промисловість. Глобальна стратегія та конкурентоспроможність Китаю мають згубний вплив на нігерійську економіку. Крім текстильної промисловості, імпорт з Китаю також знищив інші галузі промисловості у різних містах Нігерї̈, що призвело до зростання безробіття 16 .

Шість із семи текстильних виробників Kaduna закрили свою діяльність до 2006 р., частково через їх неспроможність конкурувати 3 дешевим китайським текстилем і тканинами, що отримували вигоду з умов пільгової торгівлі або потрапили у Нігерію через відверту контрабанду». Рівень безробіття зріс, коли кілька інших текстильних фабрик, як наприклад «Енпі, Аба Текстиль», закрили свою діяльність. Проблеми також зростали через використання робітниками китайсь-

\footnotetext{
${ }^{11}$ Akinrinade, S., Olukoya, O. (2008), 166.

12 Oyeranti, O., Babatunde, A.M., Ogunkola, O.E. \& Bankole, A. S. (2010), 61.

13 Olawale, O., Bankole, A. \& Adewuyi, A. (2008), 8.

14 Akinrinade, S., Olukoya, O. (2008), 165.

15 Ibid, 166.

${ }^{16}$ Ndubisi, O., Kew, D. \& Tanko, Y. (2008), 179.
} 
кої мови у будівельних проектах, поряд зі збільшенням кількості китайських торговців у Нігерії17.

Безробіття є проблемою для Нігерії майже у кожному секторі, оскільки нігерійські компанії закриваються через неефективність і не конкурентоспроможність 3 китайською продукцією. Китай завжди критикували за працевлаштування великої кількості власних робітників, що збільшило китайське населення в Нігерії. Китайські компанії працюють зі своїми робітниками. Вони привозять своїх робітників 3 КНР для роботи у створених компаніях, керувати та контролювати місцевих робітників, які працюють на неї. Попри той факт, що деякі китайські компанії наймають місцевих робітників, китайські робітники переважають на цих заводах і фабриках.

Більш того, незважаючи на різні проекти, що фінансуються Китаєм, які повинні створювати робочі місця в Нігерії та відкривати більше можливостей для бізнесу, все ще $\epsilon$ велика стурбованість і посилюється скептицизм щодо цієї теми. Безробіття стало проблемою для всіх людей у країні.

Ще одним проблемним фактором зайнятості у китайських компаніях $\epsilon$ робоча сила. 3 невеликою кількістю нігерійців, які працюють у китайських компаніях, умови праці є досить складними. Профспілки неодноразово скаржилися на погане ставлення до нігерійських робітників і на низький рівень зарплатні ${ }^{18}$.

Стандарти безпеки також викликають занепокоєння. Пожежа, яка сталася у китайській компанії в місті Ікороду штат Лагос, виявила, що звичайною практикою було замикання робітників під час чергування, що унеможливлювало робітників врятуватися від загибелі ${ }^{19}$. Нігерійські чиновники повідомили про подію без подальших розслідувань інциденту. 3 огляду на корумповані тенденції нігерійських чиновників, дуже ймовірно, що інспекторів з безпеки підкупили, щоб зам'яти справу. Були і такі твердження, що китайські фірми в Нігерії жорстоко поводяться зі своїми працівниками. Умови працевлаштування нігерійців у деяких китайських фірмах не відповідають ні Закону про працю Нігерї (NLL), а ні закону Міжнародної організації праці (МОП) ${ }^{20}$.

Отже, торговельно-економічні відносини між КНР і Нігерією на початку XXI ст. $є$ доволі проблемними. Хоч Нігерія й отримує кредити, позики та прямі іноземні інвестиції з Китаю та експортує свої нафтопродукти до КНР, у той же час існує дисбаланс між нігерійським експортом та імпортом з КНР. Імпортовані китайські товари набагато дешевші, ніж місцеві нігерійські, тому це виявило нерентабельність деяких нігерійських підприємств, особливо у текстильній сфері. Неконкурентна спроможність місцевого виробника породила зростання безробіття серед нігерійців. Детально дослідивши торговельні відносини на прикладі текстильної галузі зрозуміло, що такі чинники як контрабанда, корупція нігерійських посадових осіб і дешевизна китайських товарів, створюють зручні умови для китайського бізнесу, але при цьому ставлять економіку Нігерії у скрутне становище.

\section{REFERENCES}

Akinrinade, S., Olukoya, O. (2008). Globalization and deindustrialization: South-South neoliberalism and the collapse of the Nigerian textile industry. The Global South, 2 (2), 159-170.

Egbula, M., Qi, Z. (2011). China and Nigeria: A powerful south-south alliance. West African Challenges.

Mthembu-Salter, G. (2009). Elephants, ants and superpowers: Nigeria's relations with China. South African Institute of International Affairs.

Ndubisi, O., Kew, D. \& Tanko, Y. (2008). «Peaceful rise» and human rights: China's expanding relations with Nigeria. In Robert I. Rotberg (Ed.). China into Africa: Trade, aid and influence.

17 Ndubisi, O., Kew, D. \& Tanko, Y. (2008), 180.

${ }^{18}$ Egbula, M., Qi, Z. (2011), 18.

19 Taylor, I. (2007), 633.

${ }^{20}$ Olawale, O., Bankole, A. \& Adewuyi, A. (2008), 7. 
Ogunsanwo, A. (2008). A tale of two giants: Nigeria and China. In Kweku Ampiah, Sanusha, Naidu (Eds.) Crouching tiger, hidden dragon Africa and China (pp. 192). Scottsville, South Africa.

Olawale, O., Bankole, A. \& Adewuyi, A. (2008). China-Nigeria economic relations. AERC Scoping Studies on China-Africa Relations.

Oyeranti, O., Babatunde, A.M., Ogunkola, O.E. \& Bankole, A.S. (2010). China-Africa investment relations: A case study of Nigeria. African Economic Research Consortium (AERC).

Rindap, M.R. (2015). An Assessment of Nigeria-China Economic Relations from 1999-2014. International Journal of Arts and Humanities, 4 (1), 18-30.

Taylor, I. (2007). China's relations with Nigeria. Round Table, 96 (392), 10, 631-645.

Iryna Habro,

Petro Mohyla Black Sea National University, Mykolaiv, Ukraine ORCID: https://orcid.org/oooo-ooo1-8215-7615

Artur Akopov, Petro Mohyla Black Sea National University, Mykolaiv, Ukraine ORCID: https://orcid.org/oooo-0oo2-2252-8565

\section{The problems in Nigeria-PRC trade and economic relations at the beginning of XXI century}

Nigeria and the People's Republic of China have developed close relations, which include: Chinese infrastructure projects, investments, loans, trade agreements, technology transfer, cultural exchange etc. Nigeria is one of the fastest growing countries in tropical Africa. The most important source of Nigeria's state budget is the export of mostly crude oil and other natural resources. So China has an interest in relations with Nigeria, giving a lot of loans, investing in Nigerian infrastructure, creating Chinese cultural centers throughout Nigeria.

Nevertheless, trade and economic relations between China and Nigeria are quite problematic at the beginning of the 21st century. The main problem is the imbalance between Nigerian exports and imports from China. Imported Chinese goods are much cheaper than local Nigerian ones, so this has made some Nigerian companies unprofitable, especially in the textile sector. The non-competitiveness of the local producer has led to rising unemployment among Nigerians. Examining trade relations in detail on the example of the textile industry, it is clear that factors such as smuggling, corruption of Nigerian officials and the cheapness of Chinese goods create favorable conditions for Chinese business, but at the same time puts the Nigerian economy in a difficult position.

The trade and economic relations between China and Nigeria are an example of a relationship between two asymmetric actors in international relations, where the stronger actor (China) promotes his interests more successfully and effectively than the weaker one (Nigeria). This study is relevant against the background of global dependence on Chinese products, which displaces the local producer because of its cheap price, such consequences have already led to aggravation of China's trade relations with the United States, which escalated into a tariff and trade war.

Keywords: Nigeria, PRC, trade relations, economic relations, investments, loans, export, import, textile, unemployment 